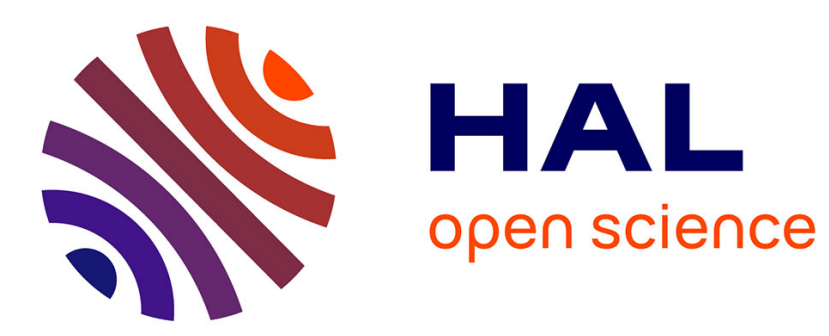

\title{
ON REPRESENTATION AND POWER: PORTRAIT OF A VODUN LEADER IN PRESENT-DAY BENIN
}

\author{
Emmanuelle Kadya Tall
}

\section{To cite this version:}

Emmanuelle Kadya Tall. ON REPRESENTATION AND POWER: PORTRAIT OF A VODUN LEADER IN PRESENT-DAY BENIN. Africa, 2014, 84 (2), pp.246-268. 10.1017/S0001972013000764 . hal-01435644

\section{HAL Id: hal-01435644 \\ https://hal.science/hal-01435644}

Submitted on 19 Jan 2017

HAL is a multi-disciplinary open access archive for the deposit and dissemination of scientific research documents, whether they are published or not. The documents may come from teaching and research institutions in France or abroad, or from public or private research centers.
L'archive ouverte pluridisciplinaire HAL, est destinée au dépôt et à la diffusion de documents scientifiques de niveau recherche, publiés ou non, émanant des établissements d'enseignement et de recherche français ou étrangers, des laboratoires publics ou privés. 


\section{On Representation and Power: Portrait of a vodun leader in present-day Benin*}

Following the 1990 National Conference, in February 1993, a Vodun Art and Culture Festival was organised under the aegis of Nicephore Soglo, the first elected president of the Benin republic after the reinstatement of democracy. Labelled Ouidah 92, this festival was initially to be held in 1992 in the former slave trade post, but had to be postponed until February 1993 because of delays in the preparatory work. The main aim of this festival was to replace the painful memory of the slave trade for the descendants of slaves in the New World, by a transnational dialogue revolving around a shared vodun culture.

Along the beach at Ouidah, temporary tiers of seats had been installed with their backs to the sea, for the numerous representatives of the African diaspora who had come from the four corners of the world to take part in the parade of vodun deities. Once on the spot, and before the beginning of the festival, I was taken aback to see that leading the very first groups of the parade, was the head of a Tron ${ }^{2}$ cult whom I had met many a time in the 1980s. He lived in one of the slums of Cotonou, in the Houeyiho district and his followers belonged to the most destitute group of men and women who had moved to the economic capital of the country, fleeing poverty and/or family conflicts. His Tron was very fierce in nature and his followers would be caught up in very aggressive trances reminiscent of the social violence with which they had been confronted when arriving in the capital city, with no family nor any other form of support to help them in the urban jungle. Adumadja ${ }^{3}$ had been invited by the new chairman of the National Community of Vodun Cults in Benin (CNCVB), Sossa Guedehoungue, who had been involved in a ruthless battle with Daagbo Hunon Xuna, the person in charge of local cults at Ouidah, and had been awarded the running and

\footnotetext{
${ }^{1}$ Anthropologist at the Institut de Recherche pour le Développement (IRD).

2 Tron is a generic term for all the anti-witchcraft cults from northern Ghana, it consists in the offering of astronomical quantities of kola nuts, which also explains the name 'kola vodun'. Anti-witchcraft cults encompass all the cults that appeared during the slave trade or colonial period, such as Mami Wata, Tchamba, Aberewa, Atingali, etc..

* Many thanks to Christine Marteau for her great help and patience, in turning my broken English into readable academic prose.

${ }^{3}$ Usual title for the chiefs of the Atingali cult.
} 
religious management of the festival ${ }^{4}$. His reputation stemmed from a personal vodun cult that he had put at the disposal of many politicians and businessmen in Central Africa and it is thanks to his personal wealth, prodigality and international networks in Africa that he managed to oust his competitor representing at the time a form of tradition and the legacy of the former authoritarian regime.

Guedehoungue's chairmanship marked the advent of deities hitherto scorned by the proponents of more ancient cults in the vast vodun pantheon. When I first started my investigation in Benin, I noticed how very dynamic these cults and their leaders were, responding much more quickly to the problems of their countrymen. Perfectly attuned to their time, these religious leaders interacted with the diaspora insofar as their own cults had appeared on the former Slave Coast following the radical transformations of societies confronted, first with the Atlantic slave trade and then, with European colonisation. Indeed, the encounter of these cults with world religions (Islam and Christianity) is part and parcel of their history.

Twenty years have gone by since the 92 Ouidah Festival, in the course of which vodun harking back to pre-colonial times have been gradually overtaken by dynamic anti-witchcraft leaders whose networks extend way beyond the strictly religious framework.

In this paper, I shall consider the way in which some religious leaders emerged as mediators between the state, civil society and the transatlantic African diaspora at the beginning of the 1990s. After a brief historical and socio-political overview of the relationship between the state and vodun cults in pre-colonial times, I shall suggest a portrait of a Tron leader who, in the wake of the 92 Ouidah festival, managed to extend his power gradually, through increased responsibilities given to him under successive governments. Today, this Tron leader is both a traditional practitioner rooted in a national and international environment, a sustainable development activist who promotes equally forcefully the heritage value of ancestral knowledge and the acquisition of modern technical know how. He is also a provider of cultural goods and magic and religious services, and finally he acted as a representative of civil society in the last two rounds of presidential elections (2007-2011).

To portray this Tron leader who is both unique and yet at the same time representative of the theological and political dimension of religious power in present-

\footnotetext{
${ }^{4}$ For further details on this confrontation, see Tall, 1995a.
} 
day Benin, I will make use of Louis Marin's work. On the basis of an analysis of semiotic systems in various contexts (painting, philosophy, literature, anthropology) and blending pragmatic linguistics with Pascal's theory of signs, Marin demonstrates that an interpretation of these systems in theological and political terms makes it possible to account for the chiasmus between any form of power and its representations. Considering that power can only exist in its representation, Marin takes as an example Louis XIV's portrait painted by Hyacinthe Rigaud to illustrate his hypothesis. To define the historical context of his analysis of absolute power, Marin borrows the grid for reading sign from the Port-Royal's logicians as for them royal power and divine power operate by way of transubstantiation on the model of "this is my body" through the presentation of the host during the catholic ritual. The dogma of the Eucharist, through which the Port Royal Logicians developed their sign theory allows Marin to demonstrate in a very convincing fashion that might and power are inherent both in their enunciation and in their representation as a sign. From this relationship between power and representation, Marin then concludes that power only materializes in its representation, or put differently, where there is no sign, nor material underpinning, there is no power.

In Benin, to approach the sign and the processes of transubstantiation at work, I propose to study them in the context of the South Atlantic. The South Atlantic, which is marked by the Slave trade establishes one sort of power/representation where the bodies are central. There the sign shows its power of incarnation of the deities in the public performances of the religious leaders and in the experiences of their followers. The processes of transubstantiation work in the South Atlantic where the sign is the visible passion. All power and its representation literally physically take hold of the whole body of social actors as in a pantomime where the power/representation exposes itself and explodes in a thousand reflections. The metaphor of the baroque mirror becomes relevant to delimit, in these corporal exchanges, the power through which is produced not only the body of a leader but also a social body, a community of political subjects and/or followers.

To conclude, I shall endeavour to explain the processes whereby local practices and those coming from entirely different universes coexist, through the concept of the baroque mirror which I developed and tested in my analysis of the candomblé in 
Bahia $^{5}$, a possession cult usually considered as syncretic. The baroque mirror is to be viewed as a device exhibiting and intensifying the links between objects at first glance totally unrelated, whilst remaining hidden. In this fashion, everything can be seen, nothing is hidden, but what enables us to see and to believe does not belong to the realm of the visible. In deepening my exploration of power and beliefs in Benin, in the light of the brilliant analysis by Louis Marin (1986) of Louis XIV's portrait as painted by Hyacinthe Rigaud, I analyse the vodun representations, not as masks that would conceal the secret of some deities, but as portraits that would actually materialize their presence. The metaphor of the baroque mirror thus enables me to avoid interpreting the occult as a kind of new theodicy, which would explain the expansion of the market economy, all too often deemed responsible for the increase of witchcraft in postcolonial Africa.

Here the mirror is a tool for assertion, which comes to reinforce the theological and political fiction of the power-portrait. For Marin, the mirror is a device of presentation, to make/render something present such as in the picture whose opacity he is deciphering. I draw some sort of analogy between Marin's 'opacity of the painting' and the concept of the baroque mirror that I made up in my analysis of practices and body experiences in the candomblé. Both are devices whose work is made visible in the portraits. In Benin, the portrait's logic enables me to make visible the context of the South Atlantic where the body is always called upon. They are performances, incarnations, experiences and trances that the mirror's device reveals or allows us to see, or makes visible.

\section{Vodun cosmology in a long duration history}

In their work on the kingdom of Danxome and the Atlantic slave trade, historians Robin Law (2004) and Edna Bay $(1998,2008)$ explored the relationship between state power and religious organisation. Law highlighted the way in which the kingdom had gradually been structured by military, administrative and religious supervision to gain the upper hand in the slave trade. Bay, for her part, demonstrated how the kingdom weakened by the ban on the slave trade in the middle of the XIX c., found a way of

\footnotetext{
5 Tall (2012).
} 
consolidating its declining power through new religious figures ${ }^{6}$ created ex-post to celebrate the advent of different Abomean dynasties and new altars ${ }^{7}$ for the elders to commemorate ancient kings. In looking at the emergence of these new figures and objects against the logic of the portrait as suggested by Marin, one can then consider the portraits of deceased kings and their ancestors are so many mirrors directed towards itself by a decaying kingdom, to materialize the presence, through the gaze, of its own strength, its own power. With the official end of the Atlantic slave trade, the production of new figures enables Danxome to maintain its power.

The political model of Danxome was influenced by the matrilineal organisation of the Akan kingdom located to the west of its territory and the patrilineal regime of the kingdom of Oyo to the east. For the monarchy, the religious life of the kingdom was strangely enough an opportunity for the state to centralize its power while sometimes, appearing as a threat insofar as the might of certain vodun could very well kill the leader or his warriors, for instance by triggering epidemics. Such was the case for the vodun Sakpata, deity of the hot earth manifesting itself through smallpox, banned from the kingdom when several kings were wiped out by outbreaks of smallpox. Conversely, vodun perceived as allies were adored and spoiled to ensure that their powers would develop and sustain the kingdom. Worshipping this or that vodun and disregarding another was a deliberate act aimed at modifying the power of vodun in favour of the monarchy and the state. The majority of the religious leaders of the main vodun temples in the kingdom were under the authority of a Minister, responsible for religious affairs (ajaxo) who saw to it that no rebellion be harboured by these vodun temples. For instance, at Ouidah, Dan, deity of the earth protecting the defeated kingdom of Savi and represented by a snake, was demoted in favour of Andantoxu, god of the sea, meaning thereby that the prosperity of the kingdom came from the sea trade. However, by reversing the order between the two local gods, the kingdom was guaranteeing its power doubly so, by stressing the role of the sea, the source of new riches with the slave trade, whilst consolidating its command through the downgrading of the vodun protecting the vanquished kingdom.

\footnotetext{
${ }^{6}$ Nesuxwe, Toxosu, water deities manifesting themselves through monstrous children at the foundation of Abomean dynasties starting with king Kpengla who, according sources, is said to have had a disabled child.

${ }^{7}$ Asen is usually shaped by a staked conical form with rounded platforms typically decorated with cut or cast metal figures.
} 
Thousands of spiritual beings were recognised during the pre-colonial period. A distinction was made between vodun ${ }^{8}$ linked to royalty and those who weren't. Commoners also worshipped their ancestors. But the subjects of the kingdom could be part of larger extra-family communities worshipping deities related to the elements. Such vodun linked to the four elements could be worshipped on very large territories, beyond the political borders of the kingdom and could very well include followers of different nations and ethnic groups. In Danxome, many vodun came from Yorubaspeaking territories to the east: $\mathrm{Gu}$, the iron god, Legba the trickster messenger, Sakpata, the divinity of the hot earth, for instance.

Religious practice in Danxome was pragmatic, eclectic and cumulative. Thus, a vodun with a certain reputation in another community was most welcome in the kingdom. Immigrants, including war prisoners, would very often bring their deities with them and install them in their new home. The Abomean people were sometimes sent to neighbouring regions to be trained as priests for these new gods, namely when the latter had been acquired as war bounty.

To sum up, it could be said that the kingdom of Danxome used to its advantage ancestral cults, be they local or foreign, invented a number of figures to expand and consolidate its power over a territory made up of countless small kingdoms and chefferies. The Atlantic slave trade and the territorial, social and political rearrangements that ensued on the African continent reshaped the religious universe around the worship of royal, clan, lineage ancestors and Nature deities, making up vodun cosmology, as described by JM Herskovits (1938) and Pierre Verger (1957).

During French colonial rule, diaspora related cults took root on the territory of the former Slave Coast. Originating from northern Ghana, these cults had been travelling across territories since the XVII $c^{9}$. Vodun travel a lot and new figures merge when needed as accumulation and plasticity/flexibility are part of vodun characteristics ${ }^{10}$, but the acknowledgment of their power always needs to go through a process of transubstantiation. That is why a common say does maintain that vodun are like human beings, who need to eat to live. Offerings and sacrifices give them power and might by way of transubstantiation.

\footnotetext{
${ }^{8}$ Vodun can be broken down into royal, lineage, natural and personal cults, see Tall (1995b).

${ }^{9}$ See Terray $(1979)$ and McCaskie $(1981,2005)$ for an historical review of their origin and their successive metamorphoses leading to a reconfiguration of their content.

10 See Augé (1982)
} 


\section{Anti-witchcraft cults, a brief historical reminder}

Tron is in Benin a generic term for anti-witchcraft cults, which emerged at the end of the XIXc. and the beginning of the XXc. on the former Slave Coast. But they were also found at the same time in Upper Volta (present-day Burkina Faso) according to a report on fetish activities drawn up by a colonial official ${ }^{11}$ in the 1930 s. An analysis and synthesis of this report and other ethnographic material ${ }^{12}$ makes it possible to identify three main social and historical factors that fostered the emergence of these cults in the area:

The breakdown of earlier social and political structures (wars between neighbouring kingdoms that paved the way for the first settlers),

seasonal labourers travelling down the Coast from Ghana to Nigeria in cocoa plantations,

The dissemination of writing which profoundly transforms thought processes (Goody, 1986).

During the pre-colonial period and the Danxome's rule, the Aja-Fon territory was governed by social political structures delineated by vodun. The breakdown of the Danxome's kingdom, the introduction of the Christian faith and of European currency in trade relations, the advent of wage earners and urbanization all contributed to the strengthening of these new gods. Like the religions of the New World, they find in heterogeneous religious universes (Islam, Christianity, Paganism), elements consonant with one another and possible solutions to confront illness and misfortune. Thus, initially, they might have seemed like a Christian reform movement ${ }^{14}$, spurred by Christian Science ${ }^{15}$ at the end of XIX c. in Togo (see Merlo, 1950), as a form of Islamic neo-traditionalism in Upper Volta, whereas today, both in Benin and Togo, they are now

\footnotetext{
11 Merlo (1950)

12 See for instance, Morton-Williams (1956) and Apter (1993) on anti-witchcraft cults in Nigeria.

13 The CMS was founded in 1799 by missionaries belonging to the Church of England. See Peel (2001) for further details on these missions at the beginning of the colonial rule.

14 Regarding various religious transformations caused by the collapse of local dominions, see Lanternari $(1965,1966)$.

15 The healer Church founded by Mary Baker Eddy en 1875 in New England.
} 
considered by most of the people as anti-witchcraft cults having merged into the vast vodun world, even though Tron leaders claim to be oecumenical during traditional celebration feasts, such as Christmas and Tabaski ${ }^{16}$. From the onset, I first viewed them as cults of prosperity breaking away from older cults on account of their individual and mercantile features. Merlo, head of the colonial civil service in Lomé speaks in deprecating terms of "fund extortions", while noting that these "fetishists" belong to the class of trade employees, civil and military officials. He warned that "fetishism in its international guise" was politically dangerous, since in those days it was mainly migrant seasonal labourers who disseminated these 'fetishes'.

Nonetheless, in contrast to the witchcraft-modernity paradigm's point of view, in my considering witchcraft as a power to be represented to be effective, its singularity and individuality is then nothing new. Indeed, witchcraft has to be named and represented to become powerful, and as in the logic of portraiture its image is always unique, to be seen in a special context. For instance, in urban areas, even when some Benin witch hunters prefer to keep the names of witches and sorcerers concealed from their victims the present-day uniformity of social explanations that I note for illness or misfortune does go with the fact that every case is special and treated as such by all soothsayers and healers.

Throughout Aja-Fon and Yoruba lands, witchcraft is perceived in two ways. The first relates to an innate force or one stemming from maternal lineage in the evocative expression "Our mothers, the witches" (Minona). The second assumes a force acquired with the assistance of an expert possessing specific technical knowhow. Both forms of witchcraft commonly share the notion of a debt vis-à-vis a parallel world, where sorcerers feast at cannibal banquets. All vodun offer protection against witchcraft assault but anti-witchcraft cults, until recently were viewed differently from other vodun since they emerged during the slave trade and colonial rule.

Thus, Tron vodun are different from previous vodun in the history of the area not so much by virtue of their intrinsic qualities as because of the context of their rise. Whereas the itinerary of most of these religious leaders follows the usual path of conversion: disease - revelation - initiation, the misfortunes of the past tend to be overtaken by a discourse that testifies to the building of an enterprising self. Let us not

\footnotetext{
16 Tabaski commemorates in Islam Abraham's sacrifice and all Muslims are duty bound to sacrifice a ram on that day.
} 
forget that the background against which all these cults developed in the southern parts of the West African coast was that of a plantation economy which replaced the Atlantic slave trade. The emergence of wage earners modified the social relations between elders and juniors, between men and women, and in a certain way, the kola nut, the main offering in these cults, highlights this new economic order and its entrepreneurial spirit.

In the Muslim societies of West Africa, the kola nut, a rather rare fruit in the Sahel region, is to this day still considered as a sacred gift to be offered to a Marabout, in exchange for his blessing or Baraka. The kola nut could be considered as a symbol of prosperity and of the market economy. Money and wage earning work throughout the colonial rule are the new signs of power and this is why in order to ward off the jealousy or wrath of the elders as in witchcraft attacks, every individual has to find new forms of protection, more powerful than those of envious elders. Furthermore, according to Marin's analysis on power and representation, the kola nut can be construed not as a symbol but as a device which brings to the fore the fact that it produces a community through transubstantiation. Indeed, the kola nut is always shared and chewed jointly by the donor and his Marabout or Tron priest.

Cults whose leaders would organise until recently public witch-hunts have become more sophisticated, especially in urban areas, and the identification of sorcerers occurs discreetly behind closed doors. Henceforth, it is the pastors of Evangelical churches who organise proselytising campaigns by denouncing devils everywhere. However, because of their reputation for violence and undermining the establishment, Tron leaders were often accused of quackery and corruption before they came out in public and were recognised as part of vodun's cosmology at the Ouidah 92 festival.

In order to address the dynamics and representations of these cults, formerly ostracised, I shall resort to the logic of the portrait of Gbediga ${ }^{17}$, a religious leader whose career has been exemplary: its multiple facets, reconciling his therapeutic and sacred gifts with his political role in present-day Benin must be viewed as a composite image, a representation that enables one to see, and in whose reflection one can be seen, while giving rise to a community of believers.

Projecting one's gaze on objects and persons, in the logic of the portrait as developed by Louis Marin enables one to have a better grasp of what brings individuals together around certain figures and representations.

\footnotetext{
${ }^{17}$ Literally, long life in Fon (Gbe :life, diga : long)
} 


\section{Gbediga, traditional practitioner and religious leader}

When I met Gbediga for the first time, in March 2002, he was already famous with Social Sciences PhD students because of his open-mindedness and his freedom of speech regarding his religious responsibilities. He was also seeking international recognition to assist him in the pursuit of very ambitious personal projects. He had already been to Brazil with a delegation of vodun leaders, at the invitation of the Brazilian government. His visit to Brazil appeared prominently on one of the walls of his vodun temple: an image of the mermaid Yemanja had been painted on the wall and its name in Portuguese was misspelled (cereia instead of sereia) ${ }^{18}$. During his trip, he had met an Umbanda ${ }^{19}$ priestess in Rio de Janeiro, and together they had planned her visit to Benin. I had the opportunity to meet this priestess in Brazil the following year, but she never managed to go to Benin for family reasons.

When we first met, Gbediga was already a mature man but in excellent physical condition, always ready to exhibit his 'six packs' even when he wasn't making offerings to his deities. Born in the Zou province, he was also the heir to vodun Sakpata and bore the title of Assogba like all the older sons of a woman follower of this god. A year after the death of his father in 2007, he became chief of his lineage and he brought back to Cotonou, Yaa, his father's vodun.

Because of an ailment caused by sorcerers - brothers on his father's side - when he was still at school, he became involved with Tron. He bought it some thirty years ago from a famous worshipper of this vodun in the Bé district of Lomé. With a Master's degree in Economics, he started by teaching for several years in various secondary schools in Cotonou and Porto Novo before being hired as a manager by a car dealership. Six years later, he resigned to devote himself entirely to his therapeutic and religious activities. At the beginning of the eighties, he founded an NGO, registered since 2003 with the commission "Poverty eradication" at UNESCO. With this NGO, he wishes to develop an inter-African research project on what he has labelled "the Totem Geography of Africa" by associating European researchers, African traditional practitioners and

\footnotetext{
18 The symbolism of Yemanja, goddess of salty waters is the same as for Mami Wata, appearing very often next to the Tron gods, but it is much more fashionable for someone seeking international development and diaspora prestige to call his deity Nana Ceria, literally Mother mermaid, rather than Mami Wata, queen of the salty waters, and this applies to the whole of the former Slave coast.

${ }^{19}$ Like the Tron, Umbanda is a cult of possession bringing together entities from various symbolic universes.
} 
international development agents. He is also a member of other associations such as the Traditional Medicine Practitioners' Association in Benin - he is one of its officers - and of the CNCVB where he was Secretary general until its demise. Regarding the dispute between Daagbo Hunon Xuna and Sossa Guedehoungue, during the 92 Ouidah festival, Gbediga acted as a conciliator between the two men, but he was nonetheless much closer to Daagbo Hunon right up to his death ${ }^{20}$. This closeness with a traditionalist leader should be viewed as a strategy for reconciling ancient and more recent cults, a strategy which proved successful, since following Ouidah 92, both sides started participating together in the vodun festival ${ }^{21}$ as of 1996 . In 1995, the Council of the Kings of Benin appointed him Minister of Afro-American Cults, following his attendance at a congress in Brazil the year before.

Gbediga is present at all the official gatherings of vodun non and this is how he found himself in the delegation that met with the Pope in January 1993, a few days before the celebration of Ouidah 92 . He also met several times the different successive heads of government at the helm of the state since 1991, and he is also very close to a number of senior civil servants of the Ministry for Foreign Affairs, the Ministry of the Interior (Home Office) and the Ministry for Relations with Institutions, which is the successor of the former. Gbediga is the regular host, in his home, to a few American researchers who visit him in order to be initiated in the mysteries of Fa geomancy. One of his sons has been acting as an interpreter and master of Fa for his Western guests since the age of fifteen. Apart from his intercontinental trips within the framework of agreements between the Benin state and international organisations, Gbediga devotes a great deal of attention to his family and professional networks. He always attends the Tron annual festive commemoration held in the compound of his Togolese mentor. He also visits his friends' temples, in particular at Ouidah and in his native town, Cove. Like most religious leaders, he has several wives and each of them has enabled him to extend his network. His first wife is a first cousin on his father's side whereas the second one is related on her mother's side to Daagbo Hunon Xuna from Ouidah. His third wife comes from Bohicon, a town at a crossroads between the north and the south of the country

\footnotetext{
20 For more details on the conflicts around the vodun leadership in Ouidah, see Tall (2009b).

21 January $10^{\text {th }}$ is a public holiday commemorating vodun. This commemoration was devised under the Presidency of Nicephore Soglo but was actually implemented under President Mathieu Kerekou in January 1996, during his first term of office as a democratically elected president.
} 
and located in neutral territory, but close to the capital of the former kingdoms of Abomey and Allada, Aja cradle of the region.

Allada was the first stop in the migration process of the Tado princes in the XV c. and this is also the birthplace of Toussaint Louverture. With the erection of the memorial monument to the hero of the first black Republic, financed by France, the kingdom of Allada was revived and in the wake of this generous gift, undertook to rehabilitate the former royal palace and promote cooperation with local and foreign entrepreneurs in order to reap the benefits of agricultural development and a passion for its glorious past. The present king who holds a Master's degree is also related to Gbediga who readily admits that his attributions as a vodun priest have made it easier for him to access pre-colonial authorities since he also serves as secretary to the Council of Kings. His matrimonial links are in large part connected to his personal choices and ambitions. He even tried to marry an American or European woman in traditional fashion to strengthen his networks outside Africa. He hasn't yet managed to do so, probably because he doesn't seem rooted enough in African tradition in the eyes of a Western woman looking for African-ness and exoticism in order to flaunt it in the diaspora ${ }^{22}$.

Thanks to the variety of his networks, Gbediga is totally part and parcel of a religious heritage dynamic, spearheaded by his Totem geography. But he is also present inside the country in regional and inter-regional networks where his main activity is to offer magic/therapeutic and religious services. To this end, he travels regularly to Togo and Nigeria and once or twice a year to France, at the invitation of his clients.

Like many vodun leaders living in Cotonou, at Gbediga's place, temple and home are located within the same compound. When you enter, at street level, a large dark and sandy courtyard offers rows of benches, like in a classroom, where patients and clients are greeted. To the left of the threshold, the Legba messenger, a blackboard is affixed on the right side wall where one finds the announcements of the day, the $F a$ sign and recommendations as to the offerings to be made for the ritual ceremonies usually taking place at the end of the week. To the right of the threshold, one finds the Ogun and Sakpata altars. Facing the main entrance, at the back of the courtyard there are several

\footnotetext{
${ }^{22}$ I was one of those to whom he proposed. Among the examples of members of the diaspora who wed vodun priests, certainly the most famous is that of Sharon Caulder, an African-American woman who «married the vodun » with Daagbo Hunon Xuna to develop and give legitimacy to her spiritual art in the USA.
} 
altars hosting the main deities of the master of the house. The main altar, Tron Kpeto deka ${ }^{23}$ looks like a genuine Brazilian shrine. Yemanja's effigy decorates the outside wall and the semi-circular inside wall is entirely painted in white and decorated with a mural representing an angel holding a ram and appealing to Abraham, who holds his son blindfolded ready to kill him. The altar is surrounded by a low wall with two openings, one for the priest, the other for the supplicant and is filled with several piles of 'stones' wrapped up, covered with kola nuts and red palm oil in front of the trident. To its left, another room is dedicated to Tron Bawungli Ketu and behind the two altars, one finds the Osanyi bush, a forest and medicinal plant divinity where clients and followers can take their medicinal baths and where Gbediga prepares his medicine. On the right hand side of the entrance to the compound, an antechamber leads to the apartment of the first wife who sells various small items, particularly everything that is necessary for the rites (candles, perfumes, kaolin, kola nuts, etc.).

Gbediga's entire family is involved in the activities of the cult. His wives act as Tayino $^{24}$, his sons take part in the bloodletting sacrifices and vodun consultations, in $\mathrm{Fa}$ geomancy whereas his daughters handle the shops (internet café and woven items) located on the street, as an extension of the compound. Above the courtyard and the altars hosting the various vodun, Gbediga has had four storeys built to house, in the last two upper floors, his foreign guests for sessions that he organises every year during the vodun festive period (January $10^{\text {th }}$ ). The second floor houses his apartments and a reception hall where he welcomes his distinguished guests. A long narrow space, this reception hall has walls decorated with countless photographs of the landlord, pictures that show him in the company of a president of Benin, as a member of a delegation attending a conference in the US, dressed like a Mande hunter standing in the middle of a French public park, not to mention the different diplomas, in their richly decorated frames, illustrating the degrees bestowed upon him as a traditional practitioner or religious leader. Also hanging on the wall, an enlarged photocopy of the first cheque for

\footnotetext{
23 Literally Tron which owns a stone.

24 Tayino usually refers to the paternal aunt in the Aja-Fon kinship system, but also the follower who takes care of the novices and mediums. Since they are not mediums themselves they are the ones who sing the vodun chants and manage the activities of the women in the temple (dances, taboos, etc.). They are also the ones who perform the ordinary rites, such as the kola nuts, making various offerings on the vodun altars and once they reach the menopause, some of them can actually replace the religious leader when he is away.
} 
100 million CFA that he received in 2009 from the Yayi Boni government, in his capacity as President of the Endogenous Religions ${ }^{25}$.

Every weekend from Friday night to Sunday afternoon, followers and clients go to Gbediga's home to take part in ritual activities. Everyone comes with the offering prescribed by the religious leader. Thus for a ceremony that was to be held during Christmas week in December 2012, the blackboard instructed devotees to come with the following offerings: 82 kola nuts +2 packs of candles +2 bottles of perfume +2 boxes of matches $+2010 \mathrm{CFA}$ for the women and $5010 \mathrm{CFA}+1$ bottle of liqueur for the men.

While during the week, clients and followers will come in large numbers to Gbediga's place to solve various health problems or other types of misfortune, it is his wives and children who handle the rites to identify the causes and also perform the propitiatory rites that will soothe the client/patient. Gbediga only deals with recent clients and followers. For the rest, he delegates but only to members of his family. Still, every weekend, when he isn't travelling he is there to preside over the rituals, which at the one and same time afford relief and solace while strengthening his community of followers. Initiates and novices are there in large numbers to guarantee the spectacle.

Successive trances, more or less violent, occur during Friday and Saturday night while clients and spectators from the neighbourhood come in to present their compliments to the chief during the day. One never knows, during the night witchcraft accusations could be levelled at some uninformed naïve spectator. As a rule, followers arrive separately at nightfall, everyone rushes in to go and hail the local deities, whilst bowing low to the ground before saluting the master of ceremony and then the different members of the cult, abiding by a strict hierarchical order. As musicians play the drums, Gbediga's spouses and children move from one altar to the other to feed the deities with kola nuts, red palm oil, sodabi ${ }^{26}$ and poultry brought by followers with special requests. Chewing kola nuts and drinking a glass of sodabi on the part of the officiant always accompanies offerings to the deities. Any ritual act is a performance in the course of which transubstantiation is crucial. One could say, following Louis Marin's analysis of power and its representation, that all sacrificial rituals can be construed on the basis of a Eucharistic model. Or else, along the lines of Bazin's (2008) and Augé's analysis (1988)

\footnotetext{
25 The government with the consent of the various leaders of vodun associations appointed him to this position, and he is in charge of distributing this amount of money to the various regional representatives of vodun cults to maintain them.

${ }^{26}$ Palm rum distilled by local 'bootleggers'.
} 
that any "God-thing" or "Object-God" only exists as strength, power and might in their physical form. Indeed with Gbediga, but this also holds true for all the other vodun temples, the consultation of a god and his real materialisation always go hand and hand with offerings and libations shared by the deities, the officiating persons and the supplicants.

Over and beyond the three annual feasts that take place regularly at Christmas, during the Tabaski and after the commemoration of January $10^{\text {th }}$ for the revival of the principal vodun of the house, where sheep and sometimes oxen are offered, animal sacrifices boil down to poultry, and cats and $\operatorname{dogs}^{27}$ for special requests.

I often witnessed very short rituals, speedily performed, usually to protect clients and followers from spells. For instance, on a Saturday afternoon, I arrived in the middle of an exorcist session for a mother with her three children. The drums beating at a frenzied pace were being played by young boys and girls between six and ten, whilst the protagonists in the ritual were seated on a mat in front of the shrine where Gbediga was officiating. One after the other, he removed from the inside a puppy, then a kitten and finally three young chickens sacrificed in sequence, where the blood of the animals was poured in a dish that would be used to feed his Tron. He then smeared with blood the wrists, ankles, temples and sternum of the supplicants. One of his sons retrieved the dead bodies of the animals. Upon completion of the sacrifices, the supplicants entered the shrine to pray, except one of the young girls who had her period. The whole ritual did not last more than ten minutes and now Gbediga is moving towards his audience, almost exclusively made up of women, with whom he discusses in small groups. He tells me that most of them are spellbound. Many of them will spend the weekend in the courtyard of the compound, and the night in the antechambers of Gbediga's wives. And on Sunday, in the middle of the day, a shared meal will mark the end of the weekend rituals. Sharing a meal consisting of sacrificed poultry during those two days is a source of regeneration and protection for the followers.

In February 2003, I met with Gbediga in Lomé for the annual festival at his mentor's compound. Several hundred initiates had come from Abidjan to the confines of Nigeria, each and everyone of them carrying Tron Kpeto Deka 'God-Thing', so as to have their powers regenerated by the numerous sacrifices of oxen and other animals. There

\footnotetext{
${ }^{27}$ Sacrificing cats and dogs is typical of anti-witchcraft cults. They aren't commonly eaten in this part of Africa and according to what was reported to me by my Tron sources, the animals are only consumed partially by the male initiates to strengthen their anti-witchcraft powers.
} 
were more than 400 'Object-Gods' stacked up in the courtyard of the founder and every religious leader in attendance had come with his delegation of devotees to take part in the dancing and singing that would last till dawn, and start all over again at ten in the morning: The festivities would last three full days. And it was in the dark of the night that mediums would be caught up in the most violent trances, grabbing from the hands of the sacrificer the ram that had just been offered, holding them in their mouths and tottering along the street which has been closed off to traffic for the occasion, and coming back to the courtyard where they would spit out the offerings in front of the altar before collapsing in a frenzy of tremors. After those three days of profound excitement of the senses, everyone would go back home, clinging to his 'object god', which would be returned to its shrine and fed once again with the blood of a ram, to guarantee peace and prosperity for the community throughout the year.

The following Monday morning, on the way back to Cotonou with Gbediga, I noticed that he was unusually nervous, in contrast to his normally calm and restrained nature. We were driving through the suburbs of Cotonou in a collective cab and he was upset that the traffic congestion and the heat might dilute the regenerated fluids of his portable vodun. That is why he stopped in Godomey and hopped into an individual cab that would drive him home directly. This annual revival ceremony was of a grandiose and baroque nature that I frequently found in other Tron festivals.

\section{Gbediga, a mediator for civil society}

Since 2009, President Yayi Boni's government has been allocating an annual budget of 100 Million CFA to the four main religions of the country ${ }^{28}$. It is Gbediga who has been responsible since then for distributing the amount earmarked for Endogenous religions to the vodun representatives of the 12 administrative districts of the country. A little under a quarter of the budget goes to the functioning of the entity which is headquartered near St John's church in Cotonou. His executive board is fairly well balanced to the extent that every vodun class and department is represented. Oro, Egungun $^{29}$ and anti-witchcraft vodun, however, tend to prevail over natural deities. One is duty bound to note that anti-witchcraft cults and male societies dominate the vodun

\footnotetext{
28 The religions in questions are the Catholic and Protestant Churches, Islam and Endogenous Religions.

${ }^{29}$ Ancestor cults which in the past were the preserve of some Yoruba lineages and which today have been taken over by male urban elites in order to advance their political or business careers. Just like Fa geomancy and Free-Masonry, these cults operate like secret societies bringing together individuals with similar occupational interests.
} 
landscape in present-day Benin society. These cults are acquired through personal choice and enable the followers to be released from some lineage obligations, whilst not representing as drastic a breakaway as converting to the Evangelical faith.

Since the mid-1980s, Gbediga has taken part in public and political events staging vodun culture. His role as a peacemaker in disputes among vodun leaders, and more importantly, his way of standing in the background, establish him as the painter of a picture who brings to centre stage the protagonists of the painting. The latter depending on the context will extol ancient vodun culture or the African heritage of the African American diaspora, or yet again the role of pre-colonial kingdoms in the making of the artisan traditions of our heritage. The different theatres where Gbediga appears have turned him into a versatile hero ${ }^{30}$, to quote a famous Brazilian novel, capable of evolving in multiple universes and emerging as the man who can cope in any situation.

Today, Gbediga holds several positions, President of Endogenous religions, Secretary to the Council of Kings in Benin, Founder of the NGO Totem Geography of Africa, which explains why he is invited to countless congresses and debates on sustainable development, peace and civil society. In February 2010, he was invited by UNDP to take part in a workshop in New York; he also served on the Autonomous National Electoral Commission (CENA) and during the disorders that followed the first round of presidential elections on March 2011; he seemed very well informed of what was going to happen next. And thus, despite a call to protest on the part of Houngbedji ${ }^{31}$, the opposition candidate, which caused some turmoil among the members of his coalition, Gbediga predicted that the runner up would withdraw peacefully. Although fully aware of party disputes, Gbediga like most other vodun leaders is always to be found, in his action, on the side of the winning coalition ${ }^{32}$.

\footnotetext{
30 This is a reference to Mario de Andrade's book (1928), Macunaíma, a hero without any character, whose main character traverses various worlds by actually metamorphosing himself as he travels along, disregarding moral codes and in some way pooling the diversity of the Amerindian, African and European worlds that shaped the Brazilian man at the beginning of the XXc.. This novel is often considered as the forerunner of Brazilian tropicalism.

31 Adrien Houngbedji was the leader of the opposition coalition who ran against the incumbent President Yayi Boni who won the second round of elections.

32 Meera Venkatachalam (2011) described a feud breaking out in Teshi, a suburb of Accra, where antiwitchcraft mediums deliberately possessed by the spirits of the north, start reviling their ethnic allies in public, in favour of their protective deities. This resulted in the violence exacerbated by ethnic tensions between two political parties in the 2004 elections being defused. Such a situation is simply unimaginable in present -day Benin: the Tron and other anti-witchcraft cults cannot be taken over by populations of the north of the country, as they do not originate from there, not to mention the fact that violent ethnic
} 
Why is it then that Gbediga is viewed as a providential man, moving effortlessly from a domestic ritual to a vodun festival, from an administrative meeting to a UNDP conference?

He has an uncanny ability to move from one world to another. Many clients of his Tron belong to the established institutions (the Police and the Army) that maintain the monopoly of state violence. Many of his friends within government circles are attached to the magic religious services that he provides. The witchcraft model is extremely prevalent among civil servants who compete fiercely with one another and whose social promotion does not always hinge on professional skills.

\section{The Eucharistic matrix of vodun cults}

When one observes a vodun ritual, one is first and foremost engulfed in experience, in that the performance of the actors also includes the observer, who simply by being there validates the event: the rhythm of the drums, the chants of the initiated women, the sacrificial rites unleashing the trances of the mediums, everything contributes to turning the rite into a genuine experience shared by all the attendants. It has already been stressed how violent the trances of the Tron devotees can be, when during the offering of the ram, the mediums grab it and bite into it in total fusion between the individual possessed, the animal sacrificed and the god that is revered, each being a mere mirror reflection of the other, including the image of the spectators.

In all the offerings and sacrificial rituals, what happens is a transformation of the substance of animate or inanimate objects into divine bodies, which produces the mystical body of believers. Such acts have to be construed as a way of depicting the invisible as such, as a way of rendering present deities that manifest themselves. Analysing the phenomenon of transubstantiation not as a dogma but as a practice, in the wake of Ludwig Wittgenstein (1977) for whom the essence of religion resides not so much in beliefs as in sensations and practices, sheds new light on the whole question of fetishism. Wittgenstein who was wary of metaphysics and symbolic interpretations suggested that we stick to the description of facts and present them synoptically, as the way in which we see things and then draw therefrom the formal correlations on the basis of intermediary terms.

conflicts afflicting the area form a serious antidote to any attempt at secession, despite the return of regional interests in politics. 
Establishing a formal correlation between practices belonging to vastly different views on the world, actually reinforces the idea that what matters in religion is not so much beliefs as emotions and practices, in other words ultimately, experience.

In Gbediga, such an experience is renewed daily in the therapeutic rites that he performs for his patients and clients. Chewing of the kola nuts that are then shared during these private rites is part and parcel of the real presence of invoked deities and transubstantiation is accomplished and repeats itself for each and every patient or follower. It reaches its paroxysm during the annual festival commemorating the birth of Christ or Abraham's sacrifice. However, whereas during the private rites performed within his home, Gbediga is the main operator at the centre of the picture, as soon as he takes part in public rites, his position changes and he moves sideways towards the frame of the picture. Thus, most of the time, he is present as the frame defining the picture, directing the gaze, reflecting the outside and inside of the picture, what Louis Marin conveys in terms of opacity of the painting.

\section{Gbediga in the Logic of the Portrait}

Drawing upon the logic of the portrait as developed by Marin enables me to discuss the multiple facets of Gbediga as a whole making up a painting where the components appear and disappear, depending on the way one looks at them.

In the picture that Gbediga has projected in recent years, I have perceived four essential elements: (1) his physical appearance, (2) his therapeutic and ritual activities, (3) his marriage links and (4) finally his institutional responsibilities. All of these components far from being anecdotal, complement each other to form the invisible device of the baroque mirror.

Gbediga's very fit body recalls the noble demeanour of Louis XIV in Rigaud's famous painting. Just as royal attributions do not necessarily entail mastering dancing, similarly those of a religious leader do not lead to sports competition. And yet, in both cases, the presentation of a young and energetic body underscores the presence of power. Indeed it is unusual to meet in Benin, especially in urban areas, a man in his prime in such good physical condition. As a rule, power and might conjure up overweight bodies, for obesity is a sign of prosperity. However, let us point out that in some cults, followers have to be in good physical shape to perform the acrobatic dances 
honouring their gods ${ }^{33}$. And yet, dances where religious leaders are possessed are very rare since the mediums are relegated to the role of instruments of the gods. Thus, Gbediga's lean and sinewy body should not been construed as a nod to a Westernized diaspora alive to the danger of obesity, but rather as a sign of greater power than that exhibited by the overweight political and economic elites. In most West African societies, and this precedes the AIDS epidemic, the symptoms of being bewitched were to be found in the skinny bodies under cannibalistic attack. One can thus appreciate Gbediga's assertively lean body as a sign of great strength where the image of his leanness may be interpreted through the metaphor of the baroque mirror, as a reverse reflection of his power. This visible sign conceals another and the thinness due to witchcraft then makes it possible to switch from the position of a victim to that of a healer, through the control of the always invisible power of witchcraft.

Gbediga did not choose to devote his life to religious affairs to escape destitution. Like most religious leaders who acquire their vodun through a monetary transaction, illness $^{34}$ was the starting point of his calling. And yet, with a Master's in economics, he could have carried on with a teaching career or in the private sector. His choice, at first glance seemingly a return to a traditional way of life, should rather be viewed as a rational choice spurred by a fine knowledge of the rules of the IMF on good governance and sustainable development, imposed on many African countries in the mid-1980s. Realizing that working for the state or a private company would never enable him to become his own master, Gbediga chose to develop his religious gifts associated with a good knowledge of the market economy and its values. His NGO on the Totem geography of Africa extended to other countries, thanks to the workshops organized every year for the commemoration of January $10^{\text {th }}$, have turned him into a global leader. His portraits and the framed degrees decorating his reception room are an abundant testimony to this.

I have already shown how his matrimonial alliances and its networks in regions considered as the cradle of vodun culture had guaranteed him legitimacy. His closeness with an extremely traditionalist chief in Ouidah, his friendship with the new generation of educated representatives cancel out earlier conflicts between ancient and new vodun cults, and between royal dynasties and vodun. Both as regards religion and the

\footnotetext{
${ }^{33}$ Sakpata dances and dances of mask societies Egungun and Gelede are extremely acrobatic.

${ }^{34}$ Even in lineage or clan vodun, Illness or misfortune may also be a sign of being chosen.
} 
representation of pre-colonial authorities, Gbediga appears far more as a conciliator than a charismatic leader. His presence in the frame and not in the centre of the picture goes a long way to explain his social advancement, visible in the countless responsibilities bestowed upon him by various governments.

Let us recall that in the public domain, his many connections with institutions representing the pre-colonial world have served to bolster his role as a mediator between civil society and government institutions. Never the charismatic leader, he is nonetheless always there, a witness of all the major theological and political events that bring together politicians and representatives of Tradition, at election time, international meetings, whether the theme be sustainable development, peace within civil society, or the heritage and memory of the slave trade.

\section{By way of conclusion}

In referring to the logic of the portrait by Louis Marin, I wished to demonstrate first that the central role of transubstantiation was not peculiar to the Christian religion or to the figure of the despot as embodied by Louis XIV.

In Gbediga's portrait, the images though composite, can also be analysed against a Eucharistic matrix: the bodies of Gbediga and the mediums, of the sacrificed animals, the material nature of the offerings and of the Gods, are all rendered present through transubstantiation either in public or private rites. All these images of bodies incarnate are also underpinned by a narrative (legend or myth revolving around a deity and/or the encounter between men and deities), an assertive discourse (the truth of the soothsayer and of body language when gods descend to inhabit the initiates) and a prescriptive one (taboos and obligations) that produce the community of believers reinforced by a shared meal.

Gbediga's portrait has also enabled me to illustrate the way in which the presentation of his bodies, the variety of his activities turned him into a powerful and incarnate body in present-day Benin. When at home resolving his clients and followers problems, Gbediga's image incarnates the full power of a religious leader and healer. When in a public space, his figure is more ambiguous as, what is at stake is state power. As the painter analysed by Marin, Gbediga is the frame within which what is staged, is the sacred part of state power. As in a mirror, Gbediga's image is always the reflection of what is at stake. During a public festival such as the celebration of the Vodun's day, members of the government are officially present and Gbediga's image is to highlight the 
power of the state at giving it a mystical dimension. Vodun's day brings on another dimension that is also present in Gbediga's home, that of the South Atlantic World through the images of Yemanja or Mami Wata. Most of the anti-witchcraft leaders do associate Tron figures with Atlantic deities and seek for a diaspora clientele.

Other figures, however, other bodies, also exhibit their power, more often than not in an obese body or by defending stubbornly a form of traditional purism, or the opposite, mindless post-modernism, blending Eastern and African philosophical traditions to break away from the region's historical religions.

The concept of the baroque mirror, a genuine epistemological challenge developed on the basis of religious productions in Brazil was also a way for me to delve into the issue of the reflection projected by incongruous images. A portrait by isolating and reconfiguring features makes it possible to chart a sort of exploration in the space rendering him visible, from within and without. A portrait implies a relationship between an image and a body that is thus materialized and there is always a tale to make the whole illustration come alive. Whether a myth or history the tale/portrait of Gbediga ushers in the historical long duration dimension through which are discussed and recast the religious issues of the slave trade, the colonial rule period and the post-colonial era in the heritage social practices.

Thus, the approach to Gbediga's persona in its multiple facets exposes, as in a mirror, intertwined figures, which far from being superimposed, in a cumulative manner often ascribed to polytheistic cults ${ }^{35}$, echo one another and are interconnected through transubstantiation. The baroque nature of the mirror is due to the fact that the distorted images belong to distinct worlds where fiction rendered present in the rituals, leads to a juxtaposition of images belonging to worlds considered as separate. Just like Macunaíma, the hero without any character, Gbediga moves about in the device of the baroque mirror as naturally as a fish in a pond.

Paris, September 2013.

\section{References}

Andrade, Mario (de), (1928). Macunaíma, o herói sem nenhum caráter. Rio de Janeiro: Agir. 2008.

Apter, Andrew. (1993) "Atinga revisited: Yoruba Witchcraft and the Cocoa Economy, 1950-1951 ", in Jean and John Comaroff (eds), Modernity and its Malcontents. Ritual and Power in Postcolonial Africa, Chicago : University of Chicago Press: 111-128. Augé, Marc. (1982). Génie du paganisme, Paris : Gallimard.

35 See for instance, Augé (1982) 
(1988). Le Dieu objet, Paris : Flammarion.

Bay, Edna G. (1998).Wives of the Leopard: Gender, Politics and Culture in the Kingdom of Dahomey, Charlottesville, University Press of Virginia

(2008) Asen, Ancestors and Vodun. Tracing Change in African Art, University of Illinois Press : Urbana and Chicago.

Bazin, Jean. "Retour aux choses-dieux" in Des clous dans la Joconde, Toulouse: Anarchasis: 493-520.

Goody, Jack. (1979). La Raison graphique. La domestication de la pensée sauvage: Éditions de Minuit.

Herskovits, J. Melville. (1938). Dahomey, an Ancient West African Kingdom. Evanston: Northwestern University Press, vol. 1, 402 p., vol. II, 407 p. 1967.

Lanternari, Vittorio. (1965).«Syncrétismes, messianismes, néo-traditionalismes». Archives de

Sociologie des Religions, 19 : 99-116.

(1966).» Syncrétismes, messianismes, néo-traditionalismes ». Archives de Sociologie des Religions, 21 : 101-l 10.

Law, Robin. (2004). Ouidah : the Social History of a West African Slaving "Port", 17271892, Athens : Ohio University Press.

McCaskie, T.C. (1981). Anti-Witchcraft Cukts in Asante : An Essay in the Social History of an African People, History in Africa, vol. 8 :125-154.

(2005). Sakrobundi and Aberewa. Sie Kwaku the witch-finder in the Akan world. Journal des Africanistes, 75(1) :163-207.

Marie, Alain. (ed.). (1997). L'Afrique des individus, Paris : Karthala.

Marin, Louis. (1986). La parole mangée et autres essais théologico-politiques, Paris, Klincksieck/ Montréal, Boréal. Chapt. "Le corps glorieux du Roi": 195-225.

(1994). De la représentation. Paris: Gallimard.

(2006). Opacité de la peinture. Paris: EHESS.

Merlo, Christian. (1950). « Synthèse de l'activité fétichiste aux Bas Togo et Dahomey », Bulletin de l'IFAN, XII: 1155-1166.

Morton Williams, Peter.(1956). «The Atinga Cult among the South-Western Yoruba : a Sociological analysis of a Witch-finding movement ». Bulletin de l'IFAN, 18, série B, 3-4 : 3 15-334.

Peel, John. D. Y. (2001). Religious Encounter and the Making of Yoruba, BloomingtonIndianapolis : Indiana University Press.

Tall, E.K.. (1995a). «De la démocratie et des cultes vodun au Bénin», Cahiers d'études africaines, $\mathrm{n}^{\circ} 137$ : 195-208.

(1995b). " Dynamique des cultes vodun et du Christianisme Céleste au SudBénin», Cahiers des Sciences humaines, 31 (4) : 797-823.

(2003). "Les nouveaux entrepreneurs en religion : la nouvelle génération de chefs de culte, les exemples de Cotonou (Bénin) et Salvador (Brésil) », Autrepart (27): 75-90.

(2005). «Stratégies locales et relations internationales des chefs de culte au SudBénin ", in L. Fourchard, A. Mary et R. Otayek (ed.), Entreprises religieuses transnationales en Afrique de l'Ouest, Paris/Ibadan : Karthala/IFRA, 2005, p. 267-284.

(2009a). "Imaginaire national et mise en patrimoine dans l'Atlantique Sud (candomblé de Bahia et cultes vodun au Sud-Bénin) » Lusotopie, XVI(2):133-155.

(2009b). "Guerre de succession et concurrence mémorielle à Ouidah, ancien comptoir de la Traite », Politique Africaine, 115 : 155-173.

(2012). Le Candomblé de Bahia. Miroir baroque des mélancolies postcoloniales, 
Paris : Éditions du Cerf, Coll. «Sciences humaines et religions », Préface de PierreAntoine Fabre.

Terray, Emmanuel.(1979 ). «Un mouvement de réforme religieuse dans le royaume abron précolonial : le culte de sakrobundi», Cahiers d'études africaines, 73/76:143-176.

Venkatachalam, Meera. (2011). "Between the Umbrella and the Elephant: Elections, Ethnics Negotiations and the Politics of Spirit Possession in Teshi, Accra". Africa, vol. 81(2): 248-268.

Verger, Pierre. (1957). Notes sur le culte des Orisa et Vodun à Bahia, la Baie de tous les Saints, au Brésil et à l'ancienne Côte des Esclaves en Afrique, Dakar: IFAN, 1957.

Wittgenstein, Ludwig. (1977). " Remarques sur le Rameau d 'or de Frazer", Actes de la recherche en sciences sociales, vol.16(1):35-42. (translation J. Lacoste).

\section{De la représentation et du pouvoir : portrait d'un chef de culte vodun dans le Bénin contemporain}

Résumé :

Dans cet article, l'auteur s'intéresse au pouvoir des chefs de cultes vodun dans le Bénin contemporain. S'attachant plus particulièrement aux leaders de cultes anti-sorcellerie nés de la rencontre avec les religions universalistes, elle propose une analyse inspirée des travaux de Louis Marin sur le pouvoir dans sa représentation et construit son propos à travers le portrait d'un chef de culte pour échapper aux analyses fonctionnalistes en termes de pouvoir occulte ou de syncrétisme. A travers la métaphore du miroir baroque conçu comme un dispositif qui met en lumière ce qui articule des pratiques hétérogènes, E.K. Tall s'attache à ce que montrent les rituels et les pratiques d'un officiant tout en illustrant la centralité du phénomène de transsubstantiation dans la production d'une communauté de croyants.

\section{On representation and power: Portrait of a vodun leader in present-day Benin}

Abstract:

In this paper, the author discusses the power of vodun leaders in present-day Benin, and more specifically anti-witchcraft cults born from the encounter with World religions. Offering an analysis inspired by Louis Marin's theory on power in its representation, the author illustrates her analysis through the portrait of a vodun leader with a view to escape from a functionalist analysis of occult power or syncretism. With the baroque mirror metaphor conceived as a device, which underscores what it is that connects heterogeneous practices, E.K. Tall describes what is shown in the rituals and practices of a vodun leader and emphasizes the centrality of the transubstantiation phenomenon in the production of a community of believers. 